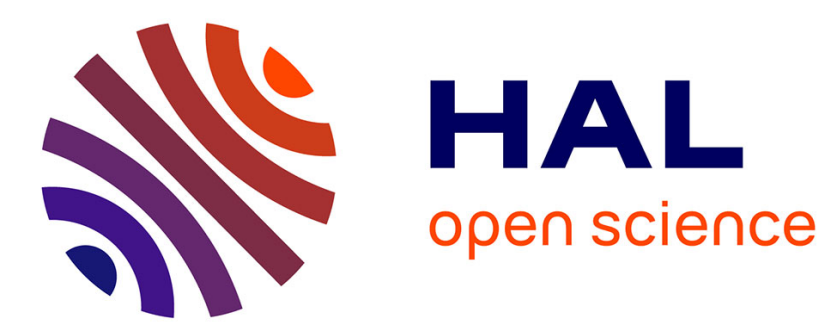

\title{
Monitoring elderly activities at home
}

Nadia Zouba, François Bremond, Alain Anfosso, Monique Thonnat, Eric

Pascual, Olivier Guerin

\section{To cite this version:}

Nadia Zouba, François Bremond, Alain Anfosso, Monique Thonnat, Eric Pascual, et al.. Monitoring elderly activities at home. Gerontechnology, 2010, 9 (2). inria-00504703

\section{HAL Id: inria-00504703 https://hal.inria.fr/inria-00504703}

Submitted on 21 Jul 2010

HAL is a multi-disciplinary open access archive for the deposit and dissemination of scientific research documents, whether they are published or not. The documents may come from teaching and research institutions in France or abroad, or from public or private research centers.
L'archive ouverte pluridisciplinaire HAL, est destinée au dépôt et à la diffusion de documents scientifiques de niveau recherche, publiés ou non, émanant des établissements d'enseignement et de recherche français ou étrangers, des laboratoires publics ou privés. 
N. Zouba, F. Bremond, A. Anfosso, M. Thonnat, E. Pascual, O. Guerin. Monitoring elderly activities at home. The elderly population is expected to grow dramatically over the next 20 years. As people grow older, they need more healthcare assistance. Without receiving sufficient care, elderly are at risk of loosing their autonomy. Thus a system permitting elderly to live safely at home is more than needed. Medical professionals believe that one of the best ways to detect emerging physical and mental health problems (before it becomes critical particularly for the elderly) is to look for changes in their activities of daily living (ADLs). For this purpose, we propose a monitoring system which aims at detecting activities of daily living (ADLs) at home. In particular, the goal is to collect and combine multisensor information to detect activities and assess behavioral trends to provide user services at different levels: (i) the elderly will feel safer at home, and (ii) the care provider will be able to provide better support via the monitoring of health trends. To reach this goal, we have designed a video understanding platform including an event recognition algorithm ${ }^{1}$. Related work includes developing and employing a variety of sensors for monitoring activities at home, including video cameras to assist person with dementia during handwashing ${ }^{2}$, and embedded sensors ${ }^{3}$ for activity recognition. Methods We propose to combine video cameras with few sensors embedded in the home infrastructure in order to recognize activities of interest at home. We propose also to describe activities with in formal models by using a dedicated description language ${ }^{1}$. The proposed system includes detecting people, tracking people as they move, recognizing events of interest and identifying a behavioral profile of a person. The potential benefit to the elderly people is that they could enjoy an increased quality of life by remaining within their own homes. The laboratory GERHOME (Figure 1) equipped with many sensors and composed of two rooms has been build at the CSTB to validate the monitoring system and to explore the ADLs that can be recognized automatically by a computer system. While living in the laboratory, fourteen elderly volunteers (aged from 60 to 85 years) have been observed during 4 hours and were asked to perform a set of household activities such as preparing meal, taking meal, and washing dishes. Results and discussion As an illustration, the recognition of the "tacking meal" activity is shown in Figure 2. Results comparing 2 elderly volunteers (male of 64 years and female of 85 years) among the 14 elderly volunteers, observed during 4 hours, show the greater ADLs ability of the 64 years old adult as compared to those of the 85 years old (Figure 3): - the younger elderly person was "bending" twice more often than the older one ( $\mathrm{NDI}=33 \%)$, and in a quicker way $(\mathrm{NDA}=60 \%)$, showing greater dynamism for the younger volunteer; - the younger elderly person (64 years old) was using more the "upper cupboard" than the other one of 85 years (NDI=42\%), and in a quicker way (NDA=65\%).

\section{References}

1. N. Zouba, F. Bremond and M. Thonnat. Multisensor fusion for monitoring elderly activities at home AVSS 09

2. Hoey J, Bertoldi AV, Mihailidis A. Assisting persons with dementia during hand-washing using a partiallw observable Markov decision process ICVS 2007

3. Wang S, Pentney W, Popescu AM, Choudhury T, Philipose M. Common sense based joint training of human activity recognizers IJCAI 2007

Keywords: ADLs, video events, environmental events, multimodal events Address: INRIA and CSTB, FRANCE;

E: nadia.zouba@sophia.inria.fr

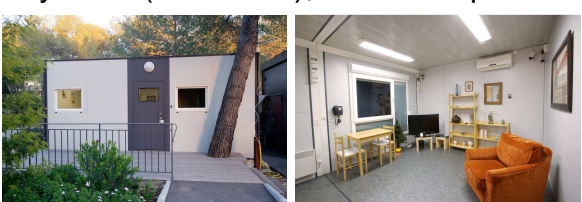

Figure 1 Gerhome laboratory pictures

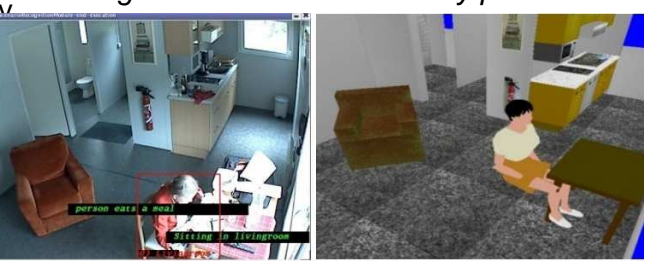

Figure 2 Recognition of "tacking meal" activity

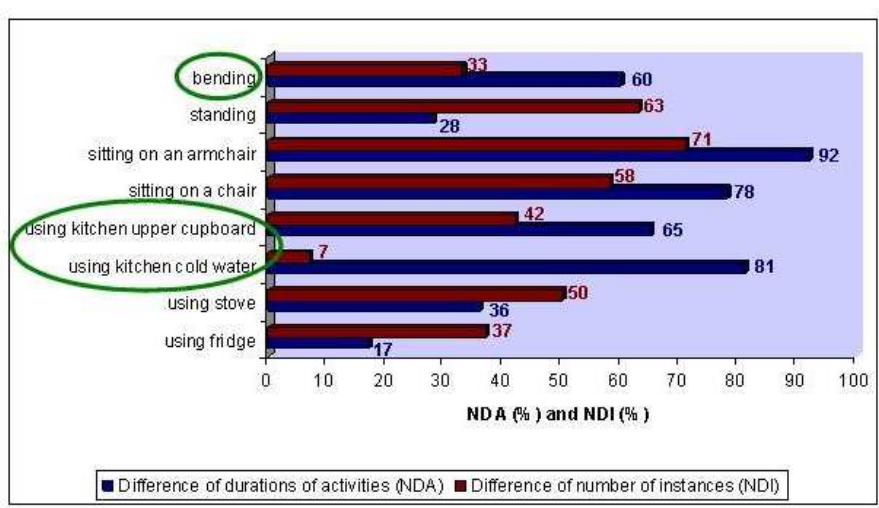

Figure 3 Results of the recognition comparing 2 elderly volunteers 